\title{
Biomass - alternative renewable energy source to the fossil fuels
}

\author{
Dorota Koruba $^{1, *}$, Jerzy Zbigniew Piotrowski ${ }^{1}$, Jolanta Latosińska ${ }^{1}$ \\ ${ }^{1}$ Kielce University of Technology, Faculty of Civil and Environmental Engineering
}

\begin{abstract}
The article presents the fossil fuels combustion effects in terms of the dangers of increasing $\mathrm{CO}_{2}$ concentration in the atmosphere. Based on the bibliography review the negative impact of increased carbon dioxide concentration on the human population is shown in the area of the external environment, particularly in terms of the air pollution and especially the impact on human health. The paper presents biomass as the renewable energy alternative source to fossil fuels which combustion gives a neutral $\mathrm{CO}_{2}$ emissions and therefore should be the main carrier of primary energy in Poland. The paper presents the combustion heat results and humidity of selected dry wood pellets (pellets straw, energy-crop willow pellets, sawdust pellets), dried sewage sludge from two sewage treatment plants of the Holly Cross province pointing their energy potential. In connection with the results analysis of these studies the standard requirements were discussed (EN 14918:2010 "Solid bio-fuels-determination of calorific value") regarding the basic parameters determining the biomass energy value (combustion heat, humidity).
\end{abstract}

\section{Introduction}

As a result of human activity we can observe rapid climate changes which are particularly evident in the increase of the greenhouse gases concentration (carbon dioxide, methane and nitrous oxide) in the atmospheric air. The anthropogenic greenhouse gas emissions are caused by economic activities especially the fossil fuels burning such as coal, oil and natural gas.[4] The carbon dioxide concentration increased for the last 200 years since the beginning of the industrial revolution when the $\mathrm{CO}_{2}$ concentration reached $280 \mathrm{ppm}$ and in 1958 it reached a value of $316 \mathrm{ppm}$. In May of $2013 \mathrm{CO}_{2}$ concentration for the first time exceeded $400 \mathrm{ppm}$, in March 2016 exceeded 405ppm (Fig.1) in the graphs rapid and continual increase in the this gas concentration is shown.

\footnotetext{
* Corresponding author: dkoruba@tu.kielce.pl
} 


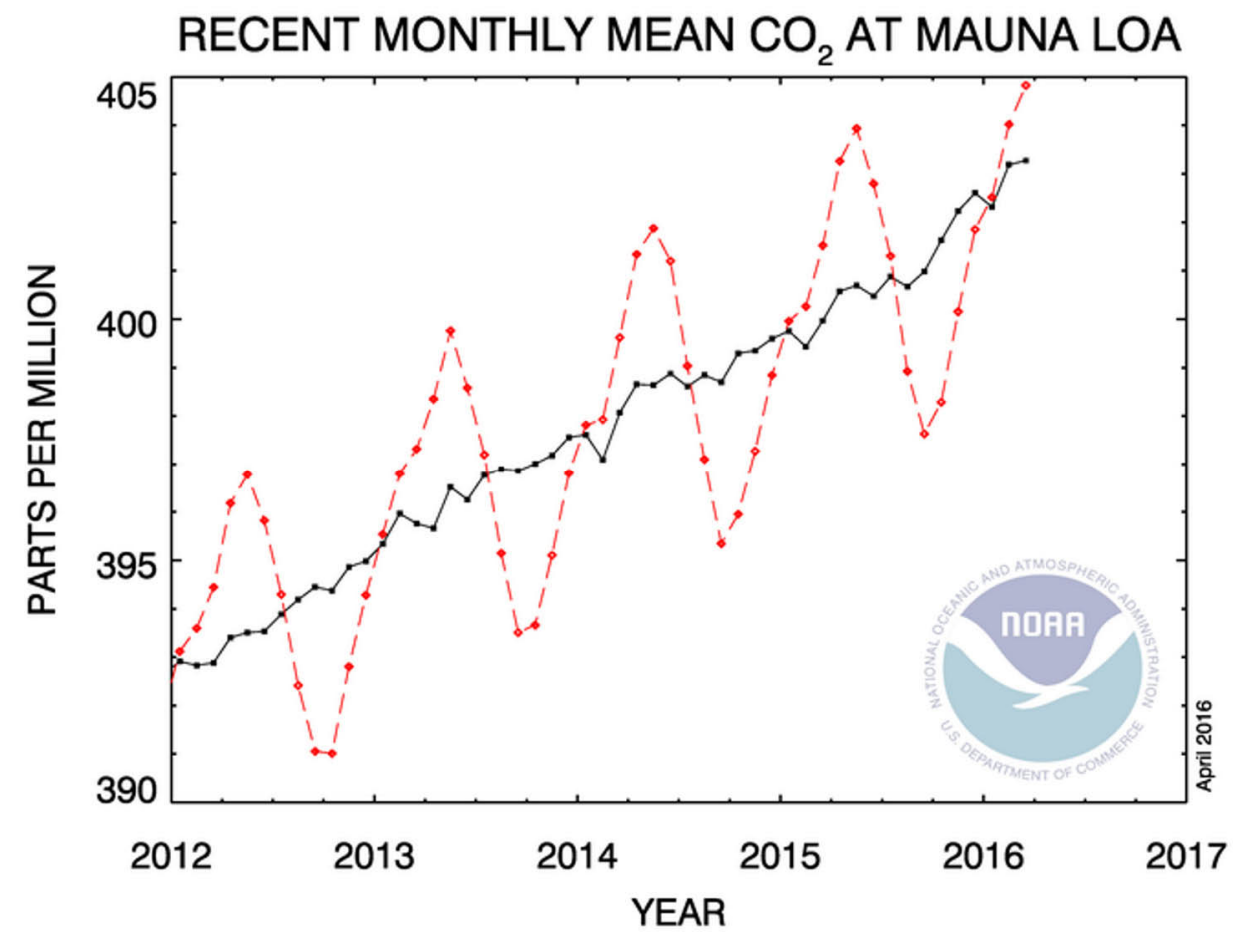

Fig. 1. The carbon dioxide concentration measured at Mauna Loa observatory in Hawaii. Source: Earth System Research Laboratory, Global Monitoring Division (http://esrl.noaa.gov/gmd/ccgg/trends).

The climate change effects observed in all natural systems, among other hydrological systems (melting snow, glaciers), which cause changes in water resources in terms of quality and quantity as well as land-based systems, eg. change in the species geographical ranges [1]. The negative climate change effects also have an impact on the human population by the presence of extreme weather conditions (high temperatures - drought, heavy rain - floods, hurricanes and fires) which also affect crops, residential and public buildings.[8] Increasing the carbon dioxide concentration results in an increased number of fungi spores (Alternaria spp., Cladospirium spp., Penicillium spp., Aspergillus spp., etc.), soil bacteria and pollen (Birch, Clone, Tilia, etc.) in the atmospheric air which cause allergies, respiratory diseases in the human population[3,4,5,9]. With the increase of carbon dioxide concentration in the atmospheric air the gas concentration in indoor air also increases[16].

The carbon dioxide high concentrations cause fatigue, headaches, dizziness, disorientation, breathlessness to the humans and in combination with carbon monoxide coming for example from fireplaces or cigarette smoke, through accumulation of the harmful effects of the last gas may in a longer term result in health deterioration. Above symptoms are the same as the symptoms of Sick Building Syndrome (SBS) $[1,2,5]$.

In order to stop advancing climate change, in particular increase the concentration of carbon dioxide in the air in the working biomass is proposed as an alternative fossil fuels $[6,13,14]$. Biomass can be an essential alternative to fossil fuels due to the zero carbon dioxide emission because during the combustion - $\mathrm{CO}_{2}$ emissions to the atmosphere is the same as the amount of $\mathrm{CO}_{2}$ absorbed by plants during photosynthesis[10]. As a result of photosynthesis (1),

$$
\mathrm{CO}_{2}+2 \mathrm{H}_{2} \mathrm{O} \stackrel{h v}{\rightarrow} \mathrm{O}_{2}+\mathrm{H}_{2} \mathrm{O}+\left(\mathrm{CH}_{2} \mathrm{O}\right)+470 \mathrm{~kJ}
$$


and specifically carbohydrate synthesis of 1 carbon dioxide mole accumulates chemical energy of $470 \mathrm{~kJ}$. During the year on the earth the biomass amount produced by photosynthesis can be 220 bln tones of dry weight. Therefore the energy contained in the biomass can be a significant contribution as a renewable energy source[12].

\section{The definition of biomass}

Directive 2001/77/EC, of the European Parliament and the Council from $27^{\text {th }}$ September 2001 on the promotion of the internal market for electricity produced from renewable energy sources has introduced a biomass definition[23].

In its meaning biomass is "the biodegradable fraction of products, waste and residues from agriculture (including plant and animal substances), forestry and related industries as well as the biodegradable fraction of industrial and municipal waste"[22-27].

On the basis of the above mentioned Directive in 2005, its interpretation of the biomass definition was also introduced by the Ministry of Economic Regulation on $19^{\text {th }}$ December 2005 on detailed duties scope to obtain and submit to the origin certificates redemption, the substitute fee and purchase of electricity and heat from renewable sources energy[27]. The Regulation defines biomass as "solid or liquid plant or animal origin, which are biodegradable, derived from products, waste and residues from agriculture and forestry, and related industries, as well as parts of other wastes that are biodegradable".

Solid bio-fuels, which include biomass, have been subjected to classification by the European Committee for Standardization CN/TC335[24], and are divided into:

- products from agriculture and forestry,

- plant waste from agriculture and forestry,

- plant waste from food processing industry,

- wooden waste with the exception of wood waste which may contain halogenated compounds or heavy metals, which are a result of wood treatment and waste from construction and demolition sites.

\section{Methodology of experimental studies of selected biomass pellets and dried sewage sludge}

\subsection{Materials and research methods}

The research material: willow pellets, sawdust pellets, straw pellets, sewage sludge (Sewage sludge "S" from the sewage treatment plants in Sitkówka-Nowiny (S), subjected to the anaerobic stabilization, dewatered and dried in disk. The nominal capacity of the plant is 72 $000 \mathrm{~m}^{3} / \mathrm{d}$ at load of $275000 \mathrm{RLM}$. Sewage sludge " " from the sewage treatment plants in Olsztyn, subjected to the anaerobic stabilization, dewatered and dried in disk. The nominal capacity of the plant is $34767 \mathrm{~m}^{3} / \mathrm{d}$ at load of $\left.350000 \mathrm{RLM}\right)$.

Research material in the form of pellets was grinded and then separated into fractions with dimensions of $0.5 \mathrm{~mm}, 0.25 \mathrm{~mm}, 0.125 \mathrm{~mm}<0.125 \mathrm{~mm}$. The dried sludge was fractioned with a diameter of $0.2 \mathrm{~mm}[17-21]$.

Determination of moisture content, ash, and the heat of combustion were carried out on three representative samples of all pellet fraction with a molecular diameter $1 \mathrm{~g}$.

When testing the moisture content of the sample in a closed crucible was dried at $105^{\circ} \mathrm{C}$ for 30 minutes. Drying was repeated until the difference in weight between weighing does not exceed $0.5 \%$ of absolute. Samples were weighed with the accuracy $0.0001 \mathrm{~g}$. 
Prior to the ash content determination the samples were dried to constant weight at $105^{\circ} \mathrm{C}$ for 30 minutes in closed crucibles. Examination of ash content was carried out at a temperature of $815^{\circ} \mathrm{C}$. Samples were weighed with the accuracy $0.0001 \mathrm{~g}$.

\subsubsection{Measuring the combustion heat of selected biofuels}

Applied Technologies: calorimeter KL-12Mn, decomposition vessel (bomb), bottle with pure oxygen, PC, analytical scale, knife grinder for Biomass LMN 100, bio-fuels hydrometer BIO1 , vibrating shaker.

The methodology of research in the field of combustion heat is based on the PN-EN 14918:2010 "Solid bio-fuels - Determination of calorific value"[17], which specifies a method for solid fuel calorific calculations at a constant volume and at $25^{\circ} \mathrm{C}$ in a calorimeter bomb.

The heat of combustion is the amount of heat, which separates the complete combustion of the fuel mass units, when the combustion process is carried out at constant volume in an atmosphere of gaseous oxygen under the assumption that the temperature of the fuel prior to combustion temperature of the combustion products is $20^{\circ} \mathrm{C}$, the products combustion $\mathrm{CO}_{2}$ and $\mathrm{SO}_{2}$ are in the gaseous state has not oxidized nitrogen and water content of the fuel by burning and formed during combustion due to oxidation of hydrogen is in the liquid.

The solid bio-fuels combustion heat studies were calculated on the basis of calorimetric research, according to the formula:

where:

$$
Q=K \quad\left(\begin{array}{lll}
T_{3} & T_{2} & k
\end{array}\right)\left[\frac{J}{g}\right]
$$

$Q$ - The heat of combustion of fuel samples $[\mathrm{J} / \mathrm{g}]$

$K$ - Calorimeter constant

$T_{2}, T_{3}$ - temperature characteristic of the balance sheet

$k$ - correction for heat exchange with the environment calorimeter

where:

where:

$$
k=0,5 \quad\left[0,2 \quad\left(T_{2} \quad T_{1}\right)+0,2 \quad\left(T_{4} \quad T_{3}\right)\right]+0,2 \quad\left(\begin{array}{ll}
n & 1
\end{array}\right) \quad\left(\begin{array}{lll}
T_{4} & T_{3}
\end{array}\right)
$$

$n$ - number of minutes in cycle 2

$T_{1}, T_{4}$ - temperature characteristic of the balance sheet

The work of the calorimeter is divided into 5 cycles:

0 - the inclusion of the calorimeter and stabilize the temperature inside the calorimeter (cycle time is approx. 2 minutes).

1 - recording the temperature $T_{1}$ and measure a time interval equal to 5 minutes.

2 - recording the temperature $T_{2}$ and the ignition of the fuel sample in a bomb calorimeter, this cycle continues until reaching its maximum temperature.

3 - registration $T_{3}$ (maximum) and the measurement of the next section of time equal to 5 minutes.

4 - registration of temperature $T_{4}$ and finish the job 


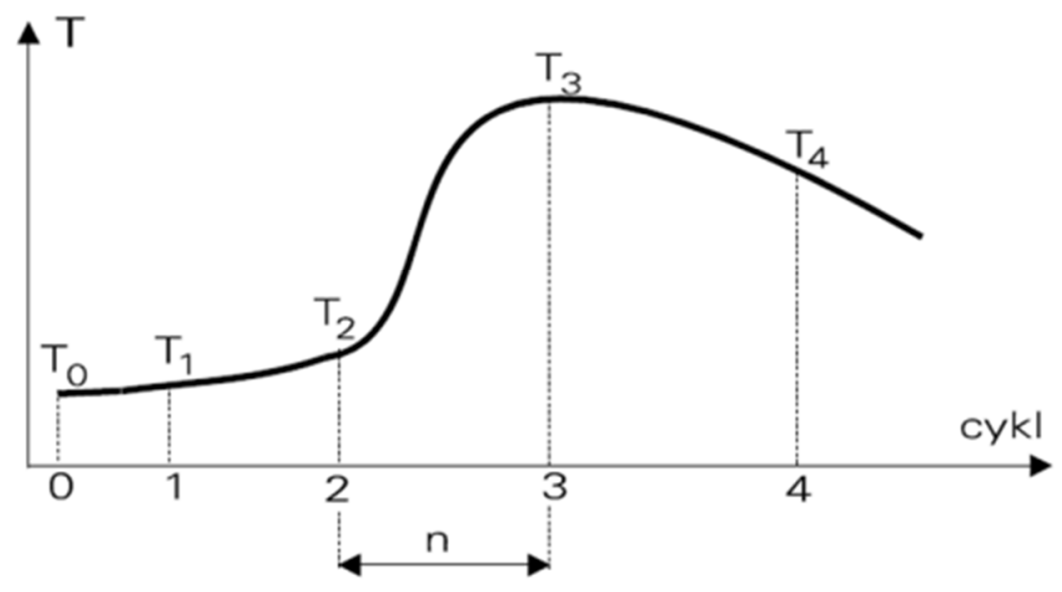

Fig. 2. Changes in temperature measurement cycle in the calorimeter.

The heat of combustion is called the upper calorific value, since it corresponds to the total heat produced from the fuel. The calorific value is a measure of the amount of heat obtained by combustion of unit of mass (or volume) of fuel.

The calorific value of organic substances containing carbon, hydrogen, sulfur and oxygen is described by the following empirical equation:

$$
W_{u}=33900 \mathrm{C}+121000\left(\mathrm{H}_{2} \frac{\mathrm{O}_{2}}{8}\right)+10500 S \quad 2500\left(W+\frac{9}{8} \mathrm{O}_{2}\right)\left[\frac{\mathrm{kJ}}{\mathrm{kg}}\right]
$$

where: $\mathrm{C}, \mathrm{H}_{2}, \mathrm{O}_{2}, \mathrm{~S}$ are mass participation of these elements, respectively $W$ is contents of water (humidity of material).

\subsubsection{Measuring the moisture content of selected biofuels}

Applied Technologies: analytical scale, laboratory oven.

The research method in determining the moisture content in the tested specimens prepared on the basis of PN-EN ISO 18134-1:2015-11, "Solid Bio-fuels - Determination of Moisture Content - Drier method - part 1: Total Moisture - Reference Method"[20]. Test methods described in this International Standards applies to all solid bio-fuels. The moisture content of solid bio-fuels (in the operating state) is always given in relation to the total weight of the test specimen (wet state).

Moisture content $\left(\mathrm{W}^{\mathrm{a}}\right)$ of biomass in the test sample is calculated by the formula:

where:

$$
W^{a}=\frac{m_{2}-m_{3}}{m_{2}-m_{1}} \quad 100 \%
$$

$m_{1}$ - is the mass of the empty drying container, in $\mathrm{g}$;

$m_{2}$ - is the mass of the drying container and test portion before drying, in $\mathrm{g}$;

$m_{3}$ - is the mass of the drying container and test portion after drying (weigh when still hot), in $\mathrm{g}$; 


\subsubsection{The measurement of the ash content in selected biofuels}

Applied Technologies: muffle furnace, analytical scale

Research methodology for the ash content determination in the tested specimens was calculated on standards: PN-ISO 1171:2002, PN-EN ISO 18122:2016-01 Solid bio-fuels Determination of Ash Content[18,19].

The ash content was calculated from the formula:

$$
A=\frac{m_{3}-m_{1}}{m_{2}-m_{1}} \times 100
$$

where:

$m_{1}$ - is the mass of the empty drying container, in $\mathrm{g}$;

$m_{2}$ - is the mass of the dish plus the test sample, in $\mathrm{g}$;

$m_{3}$ - is the mass of the dish plus ash, in $\mathrm{g}$;

\section{Test results and discussion}

The combustion heat, ash and moisture content form the basis for the solid fuels technical evaluation in terms of their suitability for energy purposes. For each tested pellets fraction moisture was examined, combustion heat and ash. The combustion heat, moisture and ash content test results in the tested specimens are shown in Table 1 and figure 3,4.

The ash content results is expressed as the average weight of two measurements with an accuracy of $0.1 \%$. The results from two tested specimens calorific determinations did not differ among themselves more than $120 \mathrm{~J} / \mathrm{g}$, the result is given as the average arithmetic number of the determinations.

Table 1. Results of combustion heat, calorific value and ash investigated pellets

\begin{tabular}{|c|c|c|c|c|c|}
\hline $\begin{array}{c}\text { The } \\
\text { research } \\
\text { material }\end{array}$ & Fractions & $\begin{array}{c}\text { Moisture } \\
{[\%]}\end{array}$ & $\begin{array}{c}\begin{array}{c}\text { Combustion } \\
\text { heat }\end{array} \\
{[\mathrm{MJ} / \mathrm{kg}]} \\
\end{array}$ & $\begin{array}{c}\text { Calorific } \\
\text { value } \\
{[\mathrm{MJ} / \mathrm{kg}]}\end{array}$ & $\begin{array}{l}\text { Ashes } \\
\text { A [\%] }\end{array}$ \\
\hline \multirow{4}{*}{$\begin{array}{c}\text { Willow } \\
\text { pellet }\end{array}$} & $0.5 \mathrm{~mm}$ & 6.13 & 21 & 20 & 0.7 \\
\hline & $0.25 \mathrm{~mm}$ & 6.09 & 22 & 21 & 0.9 \\
\hline & $0.125 \mathrm{~mm}$ & 6.20 & 23 & 23 & 1.1 \\
\hline & $<0.125 \mathrm{~mm}$ & 6.48 & 22 & 21 & 1.5 \\
\hline \multirow{4}{*}{$\begin{array}{l}\text { Gray } \\
\text { straw } \\
\text { pellet }\end{array}$} & $0.5 \mathrm{~mm}$ & 7.00 & 22 & 21 & 0.5 \\
\hline & $0.25 \mathrm{~mm}$ & 7.23 & 23 & 22 & 0.7 \\
\hline & $0.125 \mathrm{~mm}$ & 6.85 & 22 & 21 & 1.0 \\
\hline & $<0.125 \mathrm{~mm}$ & 6.44 & 23 & 22 & 1.4 \\
\hline \multirow{4}{*}{$\begin{array}{c}\text { Sawdust } \\
\text { pellet }\end{array}$} & $0.5 \mathrm{~mm}$ & 6.41 & 22 & 21 & 0.6 \\
\hline & $0.25 \mathrm{~mm}$ & 6.32 & 22 & 21 & 0.8 \\
\hline & $0.125 \mathrm{~mm}$ & 6.20 & 22 & 21 & 1.3 \\
\hline & $<0.125 \mathrm{~mm}$ & 6.70 & 23 & 22 & 1.6 \\
\hline
\end{tabular}




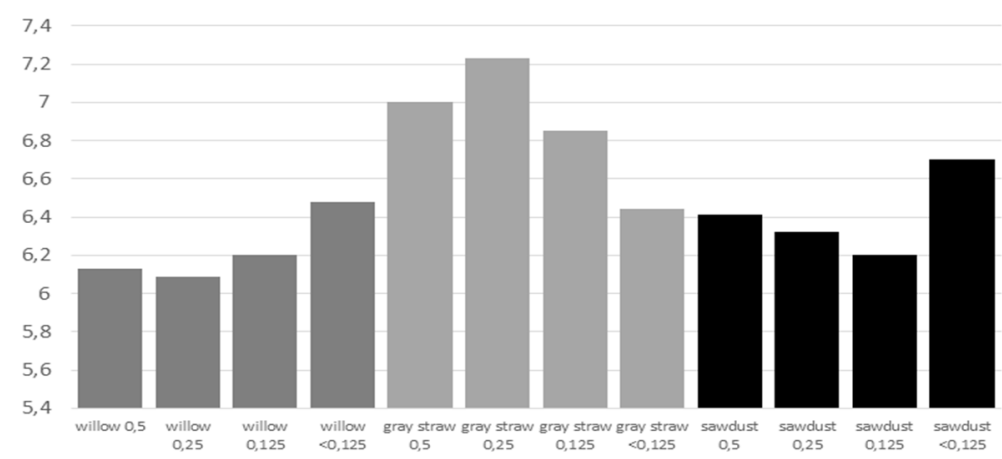

Fig. 3. Moisture particular types of pellets with the division into factions

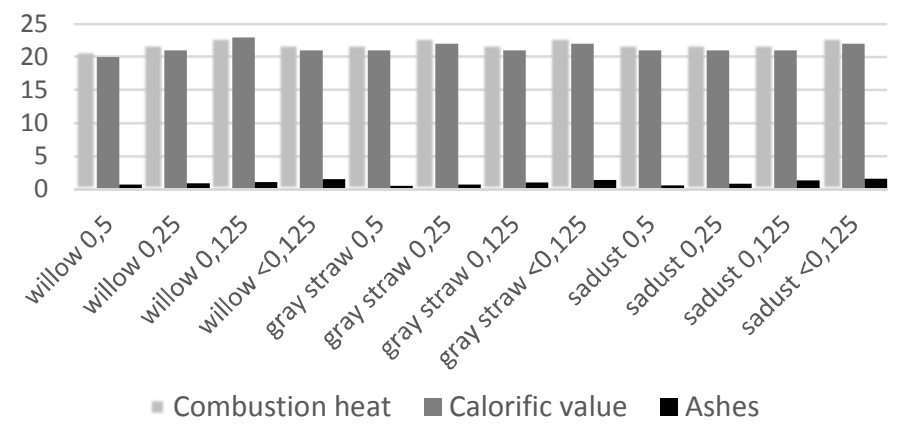

Fig. 4. Comparison of combustion heat, calorific value and ash content of pellets investigated.

The literature data and results indicate that the lower the humidity the higher the energy (eg. Gray straw fraction $<0.125$ )[7,11]. The results (table 1, figure 4) indicates that the analyzed pellets willow, straw, sawdust has a very low ash content, compared to the sludge or coal if the ash content may be approx. $22 \%$. Compared to the available technical data of coal and lignite, whose calorific value is in the range $24-31 \mathrm{MJ} / \mathrm{kg}$, the results of the tested pellets of solid biomass essentially do not differ. Indicate that it could have the potential to replace fossil fuels, renewable energy source which is biomass.

The ash content in the analyzed fuels increased with decreasing fraction used to study the material. Smaller fractions of biomass have a higher content of mineral substance in the composition.

The lack of correlation between the diameter of the fraction of the pellets tested and the result of the heat of combustion.

Table 2. Results moisture combustion heat, calorific value and ash investigated sewage sludge

\begin{tabular}{|c|c|c|c|c|c|}
\hline $\begin{array}{c}\text { The research } \\
\text { material }\end{array}$ & Fractions & $\begin{array}{c}\text { Moisture } \\
{[\%]}\end{array}$ & $\begin{array}{c}\text { Combustio } \\
\text { n heat } \\
{[\mathbf{M J} / \mathbf{k g}]}\end{array}$ & $\begin{array}{c}\text { Calorific } \\
\text { value } \\
{[\mathbf{M J} / \mathbf{k g}]}\end{array}$ & $\begin{array}{c}\text { Ashes } \\
\text { A [\%] }\end{array}$ \\
\hline $\begin{array}{c}\text { Sewage } \\
\text { sludge ,S” }\end{array}$ & $0,2 \mathrm{~mm}$ & 7,98 & 18 & 17 & 65,7 \\
\hline $\begin{array}{c}\text { Sewage } \\
\text { sludge ,L" }\end{array}$ & $0,2 \mathrm{~mm}$ & 9,43 & 17 & 16 & 67,1 \\
\hline
\end{tabular}




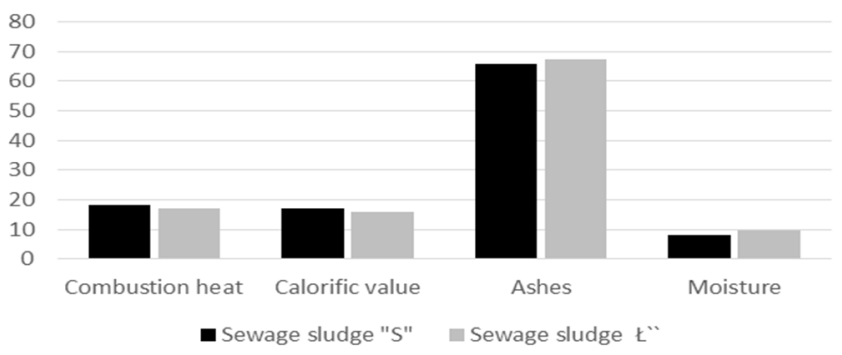

Fig. 5. Comparison moisture combustion heat, calorific value and ash content of the dried sewage sludge from two sewage.

Sewage sludge is also a "clean" biomass in terms of $\mathrm{CO}_{2}$ emissions during the combustion. However, in the sewage sludge case there is a problem with the ash content and this problem is also reflected in research methodology (PN-EN 14918:2010)[17] of combustion heat, which assumes the performance correctness of the complete specimen combustion in a calorimeter bomb[15]. In the case of sewage sludge as well as some plants species it is not possible to achieve complete combustion in a calorimeter bomb, for the sludge specimen of "L" from 1 specimen gram the residue was $0,7094 \mathrm{~g}$, in the case of sewage sludge "S" $0.6995 \mathrm{~g}$. Residues weight after combustion is similar to the ash content in the specimen. Therefore, the research methodology work should taken which will include all types of biomass.

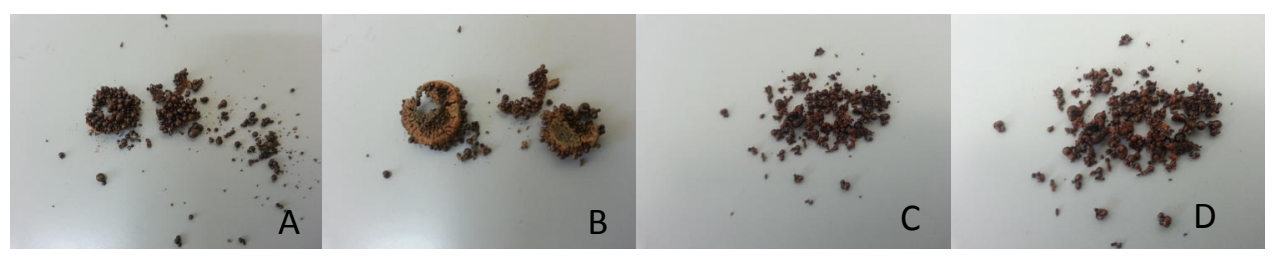

Fig. 6. Picture of the residues after combustion of $1 \mathrm{~g}$ tested specimen of the sewage sludge ' ' (pic. $\mathrm{A}, \mathrm{B})$ and 'S' (pic. C,D).

\section{Conclusion}

1. The intensive growth of emissions from the fossil fuels combustion caused air quality deterioration as well as the indoor air deterioration. Fossil fuels replacement with biomass can be of fundamental importance for the protection of public health.

2. Continuous increase in the carbon dioxide concentration increases the temperature of our planet resulting in long-lasting period the heat waves, increased the air pollution in terms of microbial contamination, fires, droughts and floods - all of these climate changes have a major impact on the human population health.

3. The results of the research will be the basis to develop their own research methods in the humidity, the heat of combustion and ashes.

3. The research on the research methodology development should be continued especially on the combustion heat of all biomass types. 


\section{References}

1. D'Amato G. et al. Meteorological conditions, climate change, new emerging factors, and asthma and related allergic disorders. A statement of the World Allergy Organization; doi 10.1186/s40413-015-0073-0; World Allergy Organization Journal 8 (25): 1-52; (2015)

2. Epstein P. R., Rogers Ch.: The impacts of $\mathrm{CO}_{2}$ and climate change on public health in the inner city - Report from the Center for Health and the Global Environment Harvard Medical School; pages:1-28; 2004

3. Lang-Yona $\mathrm{N}$.: Changes in atmospheric $\mathrm{CO}_{2}$ influence the allergen city of Aspergillus fumigatus; Global Change Biology 19, 2381-2388, doi: 10.1111/gcb.12219; (2013)

4. McMichael A.J. et al:. Climate change and human health risks and responses; WHO Library Cataloguing-in-Publication Data; ISBN 924156248 X; Geneva (2003).

5. Medina Á., Rodríguez A., Sultan Y. and Magan N.: Climate change factors and Aspergillus flavus: effects on gene expression, growth and aflatoxin production; World Mycotoxin Journal, 8 (2): 171-179; 2015

6. Mółka J., Łapczyńska-Kordon B.: Właściwości energetyczne wybranych gatunków biomasy; Inżynieria Rolnicza; 6 (131); s: 141-147; (2011)

7. Niedziółka I., Szpryngiel M.,: Ocena cech jakościowych pelletów wytworzonych z biomasy roślinnej; Agricultural Engineering; Z. 2(136) T. 1; s. 267-276; (2012).

8. Pachauri, R.K and Reisinger, A., Core Writing Team (eds.): Climate Change 2007 Synthesis Report; IPCC c/o World Meteorological Organization (WMO); published by the intergovernmental panel on climate change; ISBN 92-9169-122-4; (2008)

9. Paterson R.R.M., Lima N. Further mycotoxin effects from climate change; Food Research International Elsevier Ltd, 44: 2555-2566; (2011)

10. Roszkowski A. Energia z biomasy - efektywność, sprawność i przydatność energetyczna cz.1, 2. Problems of Agricultural Engineering; z. 1 (79); s. 97-124 (2013); z. 2 (80), s. 55-68 (2013);

11. Szyszlak-Bargłowicz J., Piekarski W., Wartość opałowa biomasy łodyg ślazowca pensylwańskiego w zależności od wilgotności; Inżynieria Rolnicza 8(117) s.: 223-230 (2009).

12. Ściążko M., Zuwała J., Sobolewski A., Przewodnik metodyczny. Procedury bilansowania i rozliczania energii wytwarzanej w procesach współspalania; Wydawnictwo Towarzystwa Gospodarczego Polskie Elektrownie i Instytutu Chemicznej Przeróbki Węgla; (2007)

13. Wasielewski R., Tora B.: Bariery stosowania paliw alternatywnych w energetyce; Polityka Energetyczna 11(2), s: 129-136; (2008)

14. Wielgosiński G. Czy Biomasa jest paliwem ekologicznym? - rozdział w monografii Polska Inżynieria Środowiska pięć lat po wstąpieniu do Unii Europejskiej. Tom. I, Monografie Komitetu Inżynierii Środowiska PAN, Lublin, vol. 58, 347-356 (2009)

15. Wielgosiński G., Nowicki M.: Badania nad termicznym rozkładem osadów ściekowych; Cieplne maszyny Przepływowe - Turbomachinery, Politechnika Łódzka, Nr 126, 181189 (2004)

16. Wolf J. et al.: Elevated Atmospheric Carbon Dioxide Concentrations Amplify Alternaria alternata Sporulation and Total Antigen Production; Environmental Health Perspectives; 118 (9): 1223-1228; (2010) 
17. PN-EN 14918:2010: „Solid bio-fuels - Determination of calorific value“

18. PN-ISO 1171:2002: "Solid fuels - Determination of Ash Content"

19. PN-EN ISO 18122:2016-01: "Solid bio-fuels - Determination of Ash Content"

20. PN-EN ISO 18134-1:2015-11: "Solid Bio-fuels - Determination of Moisture Content Drier method - part 1: Total Moisture - Reference Method "

21. PN-EN 14918:2010: "Solid bio-fuels - Determination of calorific value“

22. Dyrektywa Parlamentu Europejskiego i Rady 2009/28/WE z dnia 23 kwietnia 2009 r. w sprawie promowania stosowania energii ze źródeł odnawialnych

23. Dyrektywa 2001/77/WE Parlamentu Europejskiego i Rady z dnia 27 września 2001 roku w sprawie wspierania produkcji na rynku wewnętrznym energii elektrycznej wytwarzanej ze źródeł odnawialnych

24. CEN/TS 14961:2005 (E), Solid biofuels - Fuel Specification and Classes, CEN/TC 335 Solid biofuels; (2005)

25. Ustawa z dnia 20 lutego 2015 r. o odnawialnych źródłach energii (Dz.U. 2015 poz. 478)

26. Ustawa z dnia 27 kwietnia 2001r. o odpadach (Dz.U. $2001 \mathrm{nr} 62$ poz. 628)

27. Rozporządzenie Ministra Gospodarki. w sprawie szczegółowego zakresu obowiązków uzyskania i przedstawienia do umorzenia świadectw pochodzenia, uiszczenia opłaty zastępczej oraz zakupu energii elektrycznej i ciepła wytworzonych w odnawialnych źródłach energii; z dn. 19 grudnia 2005 r., Dz.U. 2005 nr 261 poz. 2187 